\title{
INNOVATIONS OF HISTORY EDUCATION IN THE HIGH SCHOOLS, ICSS, MALAYSIA
}

\author{
Mohamad Johdi Salleh \\ Ahmad Rafaai Ayudin ${ }^{1}$
}

\begin{abstract}
European and Asian developed countries consider History as the main subject in elementary and high schools curriculum, which is professionally reinforced in higher education. This consideration is intended to ensure that people respect leader and community contribution to maintain and develop excellences of civilization in this country. One way or another, the position of some social science subjects, including history, in today's education system are more challenged by foremost priority over sophisticated physical technology. Although it is considered as a central subject to take by high school students, its position will become vulnerable with loads of critics directed by those involved in the learning and teaching process, i.e. the students. Therefore, this paper focuses on discussion about the implementation of learning and teaching process of history from the aspects of philosophy, objectivity, the excellence of 'little historian', principles, values and citizenship. Moreover, this paper presents the results of brief analysis towards Form Four and Form Five students in Gombak and Rawang, Selangor, Malaysia. It is expected that the presentation of this paper will produce an outcome in the objectivity of integrated, quality and professional curriculum of history, especially to develop a country in this globalization era on the basis of creativity and innovation of historical education.
\end{abstract}

Key words: innovations, history education, JERISAH

\section{Introduction}

The resilient appreciation on the values of existing independence, sovereignty, and excellence of American, European, and Asian countries have regarded history as a compulsory subject in the elementary and high school curriculum. They fully consider that the existence of comfort, self-respect, nation's dignity and religion purity were acquired from great struggle of preceding leaders and society. Formal and systematic education at schools are reliable spots to ensure conscientiously that the present and next generation will respect and appreciate one another, as well as perform past-generation's attitude that are positive and constructive for generating productivity and innovation in this country for now

1 Mohamad Johdi Salleh, Ph.D is lecturer at Institute of Education, International Islamic University Malaysia (IIUM). Ahmad Rafaai Ayudin, is history teacher with 12 years of experiences at secondary school in Malaysia. Recently undertaking Ph.D in history education at Faculty of Education, National University of Malaysia. This article has been reviewed by Prof. Dr. Helius Sjamsuddin, M.A (Indonesia University of Education), and Prof. Dr. Rochiati Wiriaatmadja, M.A (Indonesia University of Education). 
and on. This correlation is demanded and actualized by many countries around this region, such as Indonesia, Thailand, the Philippines, and, Malaysia.

The above practice has inspired the Ministry of Education, Malaysia, in 1986, to decide history as a compulsory subject in the Integrated Curriculum for Secondary Schools (ICSS) or Kurikulum Bersepadu Sekolah Menengah - KBSM). In the ICSS, History subject must be taken in the national examinations by all lower secondary and upper secondary school students in every major, including arts, social science, vocational, technical, religious, and, science.

The preparation, planning, and implementation were accomplished by the History Division, Center of Curriculum Development, Ministry of Education, Malaysia, which made every effort to ensure that students would obtain optimum benefits in the process of learning and teaching of history. On the other hand, various parties, particularly the national leaders, patriots, educators, sociologists, and ministers, hold great expectations of success in history at schools. Thus, the students will become generation who committing strongly on progressive, innovative, and, harmonic genuine citizenship principles towards developed Malaysia country as aspired by the Policy of National Education, Principles of National Development, and the Vision 2020.

\section{Literature Review}

Decision to make history compulsory in curriculum of civic education has been taken for a long time by developed countries, such as United Kingdom, Germany, France, USA, Korea and Japan. This action is initiated by countries with earlier creation of world civilization along with its striking characteristics of humanity, such as Egypt maintaining the artifacts of Pharaoh-Pyramid, China being rewarding its Hwang Ho-Yang Tze valley, India perpetuating Ganges-Indus valley, Greece inheriting Roman-Spartan, Iraq appreciating Dajlah-Furat valley, and Arabian countries grateful for the land of anbiya (prophets) continuously highlighting attention up to present. Earlier civilized, modern, post modern, nuclear-powered, and cyber-information-technology countries are careful with evidence and reality, the validity of facts and the accuracy of interpretation to maintain the excellence and sovereignty of country, nation, and religion. The intellectuals, professionals, and leaders are cooperating to discover, analyze, investigate, and spread assorted facts and artifacts by describing the struggle of various level of community working together with heroes and leaders to elevate the values of independent, sovereign, respected, and progressive homeland.

The values of glory are included into KBSM curriculum of history to build awareness and develop tremendous spirit to maintain independence, defend sovereignty and actively improve the betterment of country development. Students are educated and encouraged to learn a lesson from history by implementing good examples and avoiding the wrongs. Furthermore, it is clearly stated in Al-Quran, 
the chapter of Yusof, "Surely, there are lessons in the stories of the Prophets". A good man will meet with goodness, but one in contrary will suffer a disaster. A saying of Malay proverb says that if someone ignores a lesson from history, he or she will always make a same mistake like a fox that is taken twice in the same snare. Thus, developed countries aware of and realize the values of history persistently strive for excellence by considering that today should be better than yesterday, and tomorrow should be better than today. This principle is successful to encourage Japan to become world economy booster after it was shocked by American atomic bombing in Hiroshima and Nagasaki.

It is absolutely insisted in the philosophy of education, as by Socrates, Ibn Khaldun, Toynbee, Hegel, Finberg, Zainal Abidin Wahid, and Khoo Kay Kim, and formulated by Mohamad Johdi (2000), "Since history directly deals with issues of nationality, politics and citizenship, it is very important for all students to learn this subject. This subject could be used as an effective instrument to create national identity, reinforce a sense of belonging and loyalty to the country and cultivate the spirit of patriotism. Consequently, through the acquisition of knowledge and appreciation of the country's history, it is hoped that pupils would be aware of the variety of social and national life and could this understanding foster national unity as stipulated in the Malaysian development plans".

Essentially, particular collection of facts, implementation and comprehension are being achieved by KPM through history as mechanism and spirit of citizenship and patriotism of 'Malaysia Boleh' or Malaysia Can Do. Annually toward the Independence Day, boards of schools, college, universities, and other institutions propose to undertake Patriotism Month and Week by conducting various events of memorial-tribute and declaration of intent besides the raising of country's flag. This creation is intended to actualize the independence and sovereignty of Malaysia, and every form of improvement can be fairly attained by every level of society, as it is said that 'an elephant is still an elephant when flayed; a flea is still a flea if you poke at it'.

In this respect, the Philosophy of History Education, Malaysian Secondary Schools, was formulated towards achieving these aims, to cultivate high standard moral values, the spirit of loyalty and pride in being a Malaysian. Through knowledge and appreciation of the country's history, it is hoped that the pupils would become aware of the variety of social and national order that is to be used as a main reference of fostering national unity and to reinforce the sense of belonging and the spirit of citizenship/patriotism (Curriculum Development Centre, Ministry of Education, Malaysia, 2007).

It is clear that there is a very close relation between the Malaysian Education Philosophy and the Philosophy of History in the ICSS. Consequently, the Ministry of Education (CDC 2007) decided to reformulate the aims and objectives of the old 1987 history curriculum in order to meet the aspiration of the Malaysian Education Philosophy. 
The objectives, which were built into the History Syllabus ICSS (2007), were to enable pupils to:

1. understand the political, economic and social development of the community and nation;

2. understand, appreciate and practise in daily life the Malaysian community values and culture;

3. appreciate the efforts and contributions of the national figures who have liberated and developed the nation;

4. have historical consciousness with regard to the existing community in the country;

5. analyse, synthesise and evaluate the existing historical facts and evidence rationally;

6. upgrade thinking skills and develop maturity based on students' learning experiences in history;

7. be conscious of, sensitivity to and deeply responsible for law and order and the development of the nation.

Theobjectives above are attempts for collection of facts, historian excellence, and implementation of historical lessons manifested from past events that become the primary characteristics of this country nowadays. Mohamad Johdi (2000) suggests, "the discipline of history mainly consists of 'the past', about 'real people and real events', concerns with 'sequence, time and chronology', study of 'evidence from primary and secondary sources', involves a 'work of historians particularly in understanding and interpretation of evidence' and it has 'significance with the present". In the ICSS, the elements of history were restructured through a variety of perspectives including political, economic, social, cultural and aesthetic (researcher's acronym- PESCA). This subject is closely related to other disciplines in its capacity to interconnect curriculum and turns into the only one that discuss about citizenship and civilization aspects to be attributed inside children's soul from the time when they are still at schools that is in line with Piaget's concepts of psychology. Sebba (1994) asserts that history is a splendid subject for study at any age but particularly so in school. Children are by nature curious and the past provides a feast for the curiosity.

Historical interests in the development of students' positive, critical, and creative thought are frequently described by well-known historians and researchers of historical education abroad. Some of them are Finberg (1952), Douch (1967), Stephens (1977), Hoskins (1984), Watts \& Grosvenor (1995), Jeremy Black \& MacRaild (1997), and McCullagh (1998). Recent explanation about the development of historical education is repeatedly discussed in internation journal, such as Teaching History by The Historical Association England, Welsh Historians published by Wales Historians and Journal of History Teacher published by The Association of New South Wales, Australia.

Researchers and historians also suggest that the variety of principles of learning and teaching history is students' right to achieve "progress in knowledge 
and understanding of history; ability to give historical explanation; ability to investigate and work with historical sources of different kinds; ability to provide interpretation of the past are consistent with the evidence; ability to locate, select and organize historical information; ability to present findings appropriately and effectively give historical explanations; sense of the past; awareness of how the past helped to fashion the present; enthusiasm for exploring the past; respect for evidence; toleration of a range of opinions; and, construction approach to collaborative working" (Mohamad Johdi, 2000).

The aspects described considerably influence the practicality of historical education with theintention that teachers and students will be more active, critical, creative, and innovative. The most effective principle is through an approach oriented towards the concept of 'little historian' on the basis that "the students should be given opportunity to use a range of historical sources including written evidence, artifacts, pictures, photographs, music, buildings, sites and computerbased materials. They should also be introduced to a range of perspectives such as political, economic, technological and scientific, social, religious, cultural and aesthetic. They should be actively involved in historical investigations which stem from their own interests, through asking questions, selecting and recording their own sources, organizing the information they collect and presenting their findings in a variety of ways such as orally, in writing or through model-making, pictures, drama or information technology" (Watts and Grosvenor, 1995:14).

Hence, it is obvious that learning and teaching history are in mutual accord and they should be utilized to create perfect human personality with personality proficiency of JERISAH as the essences of education principles of Malaysia, western countries, and Islam. In details, the essences are healthy, intelligent, and skillful body (Jasmani - physical); stable, harmonic, and patient emotion (Emosi - emotion); soul (Rohani - spiritual) based on the paradigm of Tauhid Syhadatain; positive, creative, and innovative intellectual (Intelektual-intellectual); effective, integrative, and appreciative socialization (Sosialisasi); everlasting, cheerful, and sophisticated nature (Alam - environment); faithful, quality, and integrated prayers for Allah (Hamba - servant of God) (Mohamad Johdi, 2008). Those proficiency and commitment have been successfully experienced by Islamic empires for eight centuries as well as by western countries based on the principles of authentic patriotism, genuine citizenship spirit, committed development, sacred morals, and rabbani civilization of 'baldatun-tayibah-warabun-ghafur' that is appreciated by partners, respected by opponents, and blessed by Allah SWT.

The personality of global, territorial, region, and local figures should become an inspiration for genuine formation and personal identity. In Asia region, it is enshrined some histories of leadership, for example from Soekarno (Indonesai), Tunku Abdul Rahman )Malaysia), Tun Abdul Razak (Malaysia), Joze Rizal (The Philippines), Chulalongkorn (Thailand), 'Gandhi (India), and Meiji (Japan). In addition, some national and religious Malay Archipelago leaders are included, 
for instance Dipo Negoro, Wali Songo, Imam Bonjol, Tok Janggut, Haji Abdul Rahman Limbung, and Syeikh Daud Al-Fatoni. These leaders and statesmen had practiced and implemented the principles of universal leadership with the concept of L.E.A.D.E.R.S.H.I.P - L-Lead, E-Educational, A-Aim, D-Delivery, E-Energetic, R-Resilient, S-Style, H-Humbleness, I-Intelligent, P-Piety (Mohamad Johdi, 2008).

Particular leaders and leadership undoubtedly may become students' rolemodels since they have discovered the missing-link for excellent sovereignty and development in their countries in accordance with the excellence of developed countries in the world.

\section{Problems, Objectives and Significance of the Study}

There is a problem with the condition of historical curriculum that is compulsorily implemented, learned, and examined at the junior high school level that is Lower Secondary Assessment (Penilaian Menengah Rendah - PMR) and high schools included in Malaysian Certificate of Education (Sijil Pelajaran Malaysia - SPM) on a same level with GCE O-level Cambridge Examination. Objectively, it is about students' accomplishment in collecting facts, understanding subjects, historical comprehension, and implementation of pure values.

Based on this credibility and significance of the subject, the researcher is inspired and obligated to examine students perception in the aspects of 'contents of syllabus', 'subject philosophy \& concept', 'goals \& objectives', 'excellence of principles', 'history across curriculum', 'learning and teaching methods', 'values \& citizenship', 'function \& benefits', and 'interest' in history at the higher secondary school level.

It is expected that the results of this research can be used effectively to overcome weaknesses and enhance the commitment of related agencies in creating versatile competent students as mentioned in the philosophy of history education that has became sacred aspiration by various developed countries around the world. Power and strength were combined to formulate and innovate the history curriculum to produce the First Class Human Capital in accordance with the aspiration of the Malaysian Education Philosophy, Malaysian Development Plan towards the achievement of Vision 2020 and 1-Malaysia.

\section{Methodology and Data Analysis}

The researcher identified that the population of this study are students of Malaysian Lower Secondary Schools involved in the ICSS. The source of information for determining the population and permission to conduct this research were obtained from the Education, Planning and Research Development 
(EPRD), Ministry of Education Malaysia, the State Education Departments of Perak and Selangor, and, the principals of respective schools.

The selection of respondents in this survey were based on the 'convenience' and 'stratified-random sampling' that involved 342 students from Lower Perak District of Perak and 342 students from Hulu Selangor District of Selangor, Malaysia. The researcher distributed the questionnaires to the respondents with the help of senior assistants and classroom teachers.

Every questionnaire was verified by the researcher to ensure that all items were responded appropriately. The data collected were processed using the Statistical Package for Social Sciences (SPSS Version 17). For content validity, the researcher sought assistance and guidance from lecturers and colleagues of the International Islamic University Malaysia (IIUM) Institute of Education(INSTED) and Faculty of Education, National University of Malaysia. The questionnaire was pilot-tested upon fifty sample students to attain reliability (Cohen and Manion 1994, Creswell 2008) and it was proved as reliable. The results of this study are displayed according to the number of responses and percentage (Best and Kahn, 1990; Coolican, 1996; and Wiersma, 2005).

As an addition, the researcher conducted an average of thirty-minute face to face group interview with forty respondents. The respondents were selected by employing convenience sampling assisted by the classroom teachers with prior permission from the school principals. The principals, teachers and students were very supportive and helpful. The interviewees were asked the standard closed and semi-structured questions which had been pilot-tested.

The total respondents were 684 students consist of $48.0 \%$ boys and $52.0 \%$ girls, $58.1 \%$ Malays, $23.4 \%$ Chinese, and, $18.5 \%$ Indians. The data were analyzed on the basis of frequency, percentage and min utilizing 4-scale and 5-scale Likert depending on the problem's identification and conformity.

\section{Findings of the Study and Discussion}

The main objective of study is to examine the students' 'acquisition and accomplishment' in learning and teaching history aspired in the philosophy, curriculum and objectives of the subject. The findings of the study are presented and discussed in the following sections.

\section{How do students perceive 'contents of education syllabus' of history?}

Respondents are given four choices related to the elements of 'contents of education syllabus' of history subject, ICSS Malaysia. The scale of their responses are 4-Very High, 3-High, 2-Low, 1-Very low. The overall findings of the study in both in Perak and Selangor are presented in Table 1 below: 
Table 5.1: Students' Perception in 'contents of education syllabus' of history, ICSS

\begin{tabular}{|c|c|c|c|c|c|c|}
\hline \multirow{2}{*}{$\begin{array}{c}\text { Perception } \\
\text { (\%) } \\
\text { Min } \\
\end{array}$} & \multicolumn{2}{|c|}{ Knowledge } & \multicolumn{2}{|c|}{ Understanding } & \multicolumn{2}{|c|}{ Interest } \\
\hline & High & Low & High & Low & High & Low \\
\hline \multirow{2}{*}{$\begin{array}{l}\text { The Text Books } \\
\text { and the elements of } \\
\text { Education Syllabus } \\
\text { of History }\end{array}$} & 72.5 & 27.5 & 66.7 & $33 \cdot 3$ & 61.4 & 38.6 \\
\hline & \multicolumn{2}{|c|}{2.2515} & \multicolumn{2}{|c|}{2.1988} & \multicolumn{2}{|c|}{2.2749} \\
\hline
\end{tabular}

Table 5.1 above shows that their response to 'contents of education syllabus' of ICSS history is less encouraging with the highest score of Knowledge $-72.5 \%$, meanwhile the scores of Understanding and Interest are $66.7 \%$ and $61.4 \%$ respectively.

S1 Discussion: This kind of situation should effectively be handled soon because this aspect is the primary concern of lesson contents - historical subject matter of ICSS that have to be comprehended and acquired well by students. Failure in this aspect will suppress 'desire and accomplishment' of learning and teaching process as well as understanding in the development of community and nation from politics, economics and social aspects.

How do students perceive 'philosophy \& concepts' of history, ICSS?

The overall responses of students in Perak and Selangor in relation to the philosophy and concepts' of history ICSS is presented on table 2 below.

Table 5.2: Students' Perception in 'philosophy \& concepts' of history, ICSS

\begin{tabular}{|l|c|c|c|}
\hline \multirow{2}{*}{$\begin{array}{l}\text { Perception/Comprehension Items } \\
\text { philosophy \& concepts' }\end{array}$} & \multicolumn{3}{|c|}{$\begin{array}{l}\text { Student Respondents (N=684) } \\
\text { 4-scale/ (Percentage/ Min) }\end{array}$} \\
\cline { 2 - 4 } & Agree & Disagree & Min \\
\hline recognizing past events & 88.9 & 11.1 & 3.1988 \\
\hline recognizing real fact or fiction & 77.2 & 22.8 & 2.9181 \\
\hline $\begin{array}{l}\text { being emphatic/imaginative about historical } \\
\text { events }\end{array}$ & 60.8 & 39.2 & 2.6082 \\
\hline correlating past and present events & 78.4 & 21.6 & 3.1579 \\
\hline utilising historical sources to solve problems & 71.9 & 28.1 & 3.0409 \\
\hline \multicolumn{1}{|c|}{ Average of Response } & 75.4 & $\mathbf{2 4 . 5 6}$ & $\mathbf{2 . 9 8 4 7}$ \\
\hline \multicolumn{2}{|c|}{} \\
\hline
\end{tabular}

Table 5.2 implies that the highest response to 'past events' of $88.9 \%$ entails that respondents have profound 'sense-concepts' of history. However, the item of 'empathy' with $60.8 \%$ as the basis for learning and teaching the subject is not successfully comprehended by respondents.

S2 Discussion: The accomplishment of $75.4 \%$ average and other items below $80.0 \%$ should be improved because students' comprehension of 'philosophy and concepts' is the main concern for learning history. Failure in comprehending 
subject 'philosophy' will affect its extent - or the parameter of learning and teaching.

How do students perceive 'aim \& objectives' of history, ICSS?

The overall responses of students in Perak and Selangor in relation to the 'aim and objectives' of history ICSS is presented on table 3 below.

Table 5.3: Students perception in 'aim \& objectives' of history, ICSS

\begin{tabular}{|l|c|c|c|}
\hline \multicolumn{1}{|c|}{$\begin{array}{l}\text { Perception/Comprehension Items } \\
\text { 'aim \& objectives' }\end{array}$} & \multicolumn{3}{c|}{$\begin{array}{c}\text { Student Respondents } \\
\text { (N=684) }\end{array}$} \\
\cline { 2 - 4 } & 4-scale (Percentage/ Min) \\
\cline { 2 - 4 } & Agree & Disagree & Min \\
\hline examining past events & 70.2 & 29.8 & 2.9123 \\
\hline $\begin{array}{l}\text { recognizing identity of oneself, nation, and } \\
\text { heritage }\end{array}$ & 82.5 & 17.5 & 3.1637 \\
\hline $\begin{array}{l}\text { examining information and its historical } \\
\text { correlation }\end{array}$ & 70.2 & 29.8 & 2.8830 \\
\hline being able to isolate information and sources & 66.7 & 33.3 & 2.9357 \\
\hline $\begin{array}{l}\text { maintaining self-conviction, curiosity, and } \\
\text { adventure }\end{array}$ & 85.4 & 14.6 & 3.1871 \\
\hline \multicolumn{1}{|c|}{ Average of Response } & $\mathbf{7 5 . 0}$ & $\mathbf{2 5 . 0}$ & $\mathbf{3 . 0 1 6 4}$ \\
\hline
\end{tabular}

The average of response to 'aim and objectives' of history is $75.0 \%$ and is simply categorized as less encouraging. There are only two items perceiving more than $80.0 \%$ of scores, meanwhile the lowest level score is $66.7 \%$.

S3 Discussion: The findings reflect that there is $25.0 \%$ weakness in accomplishing 'aim and objectives' among students in the curriculum of history, whereas, this aspect is very important to assess effectiveness and direction of learning and teaching the subject. Failure in this aspect seems like 'the ship sail without a rudder' or 'birds fly without a tail'.

How do students perceive 'basic skills' of history, ICSS?

The overall responses of students in Perak and Selangor in relation to the 'basic skills' of history ICSS is presented on table 5.4 below.

Table 5.4: Students' perception in 'basic skills' of history, ICSS

\begin{tabular}{|l|c|c|c|}
\hline \multicolumn{1}{|c|}{$\begin{array}{c}\text { Perception/Comprehension Items } \\
\text { 'excellence of principles' }\end{array}$} & \multicolumn{3}{c|}{$\begin{array}{c}\text { Student Respondents } \\
\text { (N=684) }\end{array}$} \\
\cline { 2 - 4 } & 4-scale (Percentage/ Min) \\
\cline { 2 - 4 } Agree & Disagree & Mean \\
\hline Consuming the sources well & 88.3 & 11.7 & 3.0000 \\
\hline Examining evidence to analyze history & 64.3 & 35.7 & 2.7368 \\
\hline $\begin{array}{l}\text { Maintaining empathy with past event, and present } \\
\text { correlation }\end{array}$ & 74.9 & 25.1 & 2.9298 \\
\hline
\end{tabular}




\begin{tabular}{|l|c|c|c|}
\hline $\begin{array}{l}\text { Understanding causes-and-effects, time-and- } \\
\text { changes }\end{array}$ & 78.9 & 21.1 & 2.9474 \\
\hline Skills of analyzing, and make decision & 67.8 & 32.2 & 2.8538 \\
\hline \multicolumn{1}{|c|}{ Average of Response } & 74.8 & $\mathbf{2 5 . 2}$ & $\mathbf{2 . 8 9 3 6}$ \\
\hline
\end{tabular}

The accomplishment of $74.8 \%$ average of response is less encouraging because there are more than $25.0 \%$ of respondents that do not acquire 'basic skills' of history ICSS. In addition, there is only one element that perceives over 80.0\% and other two items are below 70.0\%.

S4 Discussion: Practically, the deficiency of accomplishing basic historical skills results in students' inadequacy to improve their study skills which form critical, creative, analytical, learning and teaching process that rationally examines historical facts. Thus, it becomes more difficult to generate little historian with sufficient competence in conducting analysis and research. Motivation for learning and teaching history and implementing 'Critical and Creative Thinking' curriculum can be affected and desperately be achieved.

How do students perceive ICSS history that 'across curriculum'?

The overall responses of students in Perak and Selangor in relation to the history ICSS 'across curriculum' is presented on table 5 below:

Table 5.5: Students' perception in ICSS history that 'across curriculum'

\begin{tabular}{|c|c|c|c|c|}
\hline \multirow[t]{2}{*}{$\begin{array}{l}\text { Perception/Comprehension Items } \\
\text { 'interconnects curriculum' }\end{array}$} & \multicolumn{4}{|c|}{$\begin{array}{c}\text { Student Respondents }(\mathrm{N}=684) \\
5 \text {-scale (Percentage/ Min) }\end{array}$} \\
\hline & High & Low & Irrelevant & Min \\
\hline Mathematics & 31.6 & 45.6 & 22.8 & 1.8538 \\
\hline Science \& Technology & 49.7 & 47.4 & 2.9 & 2.5263 \\
\hline Geography & 52.0 & $33 \cdot 3$ & 18.7 & 2.1287 \\
\hline Religion & 72.5 & 22.2 & 5.3 & 2.9123 \\
\hline Painting & 68.4 & 31.6 & 15.2 & 2.4035 \\
\hline Civics \& Citizenship & 83.6 & 6.4 & 9.9 & 3.2573 \\
\hline Average of Response & 59.6 & 31.1 & 9.3 & $\mathbf{2 . 5 1 3 7}$ \\
\hline
\end{tabular}

Table 5.5 above shows that students have low perception in correlating history and others subjects given at schools. The lowest level is in the correlation of history and mathematics with $22.8 \%$ response and $1.8538 \mathrm{~min}$.

S5 Discussion: The highest accomplishment in 'Civics \& Citizenship' is as it is expected, but, still, the response of $83.6 \%$ should be improved. $9.9 \%$ disclosure of response is not correlated. History subject is fully expected to cover diverse aspiration of citizenship, especially the concepts of development, foundation of patriotism, harmony of government, and, integration. Low response to the correlation of history and Science \& Technology subject as well as Geography should also be considered appropriately. 
How do students perceive 'learning and teaching methods' of history, ICSS?

The overall responses of students in Perak and Selangor in relation to the 'learning and teaching methods' of history, ICSS is presented on table 5.6 below.

Table 5.6: Students' perception to 'learning and teaching methods' of history

\begin{tabular}{|l|c|c|c|c|}
\hline \multirow{2}{*}{$\begin{array}{c}\text { Perception/Comprehension } \\
\text { Items 'learning and teaching } \\
\text { methods' }\end{array}$} & \multicolumn{4}{|c|}{$\begin{array}{c}\text { Student Respondents (N=684) } \\
\text { 4-scale (Min) }\end{array}$} \\
\cline { 2 - 5 } & Impression & Rank & Usage & $\begin{array}{c}\text { Gap of } \\
\text { Min }\end{array}$ \\
\hline 1. Visit & 3.2632 & 10 & 1.5906 & 1.67 \\
\hline 2. Video & 3.1053 & 7 & 1.7076 & 1.40 \\
\hline 3. Computer & 2.9474 & 8 & 1.6959 & 1.25 \\
\hline 4. Gathering & 2.8480 & 5 & 2.2632 & 0.58 \\
\hline 5. Project & 2.8421 & 6 & 2.0526 & 0.79 \\
\hline 6. Play, Drama & 2.8304 & 9 & 1.5965 & 1.23 \\
\hline 7. Story & 2.7845 & 4 & 2.4035 & 0.38 \\
\hline 8. Textbook & 2.6082 & 1 & 3.1287 & -0.52 \\
\hline 9. Speech, explanation & 2.4854 & 2 & 2.6491 & -0.16 \\
\hline 10. Questioning & 2.4035 & 3 & 2.4094 & -0.04 \\
\hline Average of Response & $\mathbf{2 . 8 1 1 8}$ & & $\mathbf{2 . 1 4 9 7}$ & $\mathbf{0 . 6 6 2 1}$ \\
\hline
\end{tabular}

The Table 5.6 above asserts 'a contradiction' between impressive methods and common methods in learning and teaching of history. The method of 'visit' 1-10, 'video' 2-7 and 'computer' 3-8 receive highest scores of response but they obtain lowest level of usage. 'Textbook' 8-1, 'speech' 9-2 and 'questioning' 10-3 are less impressive, but they are frequently used. This implementation must result in conflict situation and interest decline.

S6 Discussion: This phenomenon should not be enduring because it is concerned with the increase of the number. Nevertheless, students consider that learning history is boring, uninteresting and using out-of-date 'teaching and learning' method. Teachers should be aware and conscious the principles of pedagogy, particularly to determine the most impressive principles of teaching related to particular subjects. Negative impression should be prevented to put in students' mind and performance or it could seem like saying 'expecting of becoming rich without struggling', 'expecting of becoming smart without learning', or 'expecting of becoming satisfied without eating meals'.

How do students perceive 'values \& citizenship' in history, ICSS?

The general perceptions of students in Perak and Selangor in relation to the 'values \& citizenship' in history, ICSS, is displayed on table 7 below. 
Table 5.7: Students' perception in 'values \& citizenship', ICSS

\begin{tabular}{|c|c|c|c|}
\hline \multirow[t]{2}{*}{$\begin{array}{l}\text { Perception/Comprehension Items } \\
\text { 'values \& citizenship' }\end{array}$} & \multicolumn{3}{|c|}{$\begin{array}{c}\text { Student Respondents }(\mathrm{N}=684) \\
\text { 4-scale (Percentage/ Min) }\end{array}$} \\
\hline & Agree & Disagree & Min \\
\hline democracy-based government & 66.7 & 33.3 & 2.7485 \\
\hline religion-based government & 82.5 & 17.5 & 3.0877 \\
\hline appreciating prominent figures, pure values & 87.1 & 12.9 & $3 \cdot 3977$ \\
\hline respecting laws, institutions & 87.1 & 12.9 & 3.1520 \\
\hline preserving freedom, independence & 84.2 & 15.8 & 3.0760 \\
\hline protecting country & 89.5 & 10.5 & 3.2281 \\
\hline Average of Response & 82.9 & 17.1 & 3.1150 \\
\hline
\end{tabular}

The Table above presents that the overall responses to 'values \& citizenship' are encouraging with $82.9 \%$ average in 'agree' column. Basically, respondents have awareness, sensitivity and spirit to be involved in undertaking efforts to maintain sovereignty, development and improvement of the country.

S8 Discussion: $66.7 \%$ perception in the element of 'democracy based government' is very low and it should be examined in detail. It is possible that students are able to differentiate the true theory, principle and implementation of actual democracy by comparing with appropriateness in the surroundings. This element is also related to adolescent's perception in the concept of freedom and majority in the context of inclination of adolescent psychology.

How do students perceive 'function \& benefits' of history, ICSS?

The overall perceptions of students in Perak and Selangor towards the 'function \& benefits' of history, ICSS, is shown on table 8 below.

Table 5.8: Students' perception in 'function \& benefits' of history, ICSS

\begin{tabular}{|c|c|c|c|}
\hline \multirow[t]{2}{*}{$\begin{array}{l}\text { Perception/Comprehension Items } \\
\text { 'function \& benefits' }\end{array}$} & \multicolumn{3}{|c|}{$\begin{array}{c}\text { Student Respondents }(\mathrm{N}=684) \\
\text { 4-scale (Percentage/ Min) }\end{array}$} \\
\hline & Agree & Disagree & Min \\
\hline learning history with benefits & 72.5 & 27.5 & 2.9825 \\
\hline respecting culture towards assimilation & 87.7 & 12.3 & 3.2222 \\
\hline examining lessons, improvement & 91.2 & 8.8 & 3.2047 \\
\hline proficiency of interaction, socialization & 69.0 & 31.0 & 2.9064 \\
\hline maintaining personality, solving problems & 70.2 & 29.8 & 2.8363 \\
\hline involvement in actualizing the insight of 2020 & 91.2 & 8.8 & $3 \cdot 3450$ \\
\hline $\begin{array}{c}\text { Average of Response } \\
\end{array}$ & 80.3 & 19.7 & 3.0829 \\
\hline
\end{tabular}

The Table 8 above suggests that the perception of $80.3 \%$ response average in 'benefit' is encouraging on account of two items with more than 90.0\% response. However, three items of 'interaction', 'benefits' and 'maintaining personality' perceive low response. 
S8 Discussion: The perception of low response in 'proficiency of interaction, socialization' with $69 \%$ response, 'maintaining personality, solving problems' with 70.2\% response, and 'learning history with benefits' with $72.5 \%$ response are keeping in suspense in short and long terms. Those three items are important to open students' mind and ideas inside and outside of school boundaries. Communication breakdown can be resulted from incompetence in interacting with others. Moreover, inferiority and incapability to solve problems can be resulted by disregarding the role model of authoritative former leaders, but rather by admiring recent idols with baffling credibility and contribution, particularly with Western-Eastern-style principles of entertainment that is lack of nationality and religious values.

\section{How do students perceive 'interest' in history, ICSS?}

The overall perceptions of students in Perak and Selangor towards the 'interest' of history, ICSS, is demonstrated on table 9 below.

Table 5.9: Students' perception in 'interest' of history, ICSS

\begin{tabular}{|c|c|c|c|}
\hline \multirow[t]{2}{*}{ The items of 'interest' } & \multicolumn{3}{|c|}{$\begin{array}{c}\text { Student Respondents } \\
\text { (N=684) } \\
\text { 4-scale (Percentage/ Min) }\end{array}$} \\
\hline & Agree & Disagree & Min \\
\hline respecting and updating historical development & 81.3 & 18.7 & 3.1462 \\
\hline presenting loads of problems at classroom & 72.5 & 27.5 & 2.8655 \\
\hline continuously learning history & 81.3 & 18.7 & 3.0409 \\
\hline earning excellent grade & 68.4 & 31.6 & 2.7485 \\
\hline delivering interesting teaching from the teacher & 68.4 & 31.6 & 2.8830 \\
\hline substantially contributing to future career & 59.1 & 40.9 & 2.6667 \\
\hline Average of Response & 71.8 & 28.2 & 2.8918 \\
\hline
\end{tabular}

The perception of $71.9 \%$ response average in students' 'interest' in learningteaching history is low.

S9 Discussion: Average of $28.2 \%$ response in 'disagree' column may imply that most of students are not interested to learn history, including 'teacher's teaching method', pessimistic on 'excellent grade' and its correlation with 'career'. That perception should objectively be examined through actual source. If thirty percent students are 'not interested' in history that, in one aspect, is full of lessons and guiding leadership criteria in personality creation and country development, they will also ignore that matters. The possible implication is that they will fail in their life or, even if their life is successful, they will not have genuine innovative and patriotic spirit to develop the nation, country, and religion.

\section{How do students generally perceive the 'Curriculum of History', ICSS?}

The overall perceptions of students in Perak and Selangor towards the 'Curriculum of History', ICSS, is shown on table 10 below. 
Table 5.10: Students' general perception in the History Curriculum, ICSS

\begin{tabular}{|c|c|c|c|}
\hline \multirow{2}{*}{$\begin{array}{c}\text { General Perception/ } \\
\text { Comprehension } \\
\text { Curriculum Item }\end{array}$} & \multicolumn{3}{|c|}{$\begin{array}{c}\text { Student Respondents }(\mathrm{N}=684) \\
\text { 4-scale (Percentage/ Min) }\end{array}$} \\
\hline & Agree & Disagree & Min \\
\hline Philosophy \& Concept & 75.4 & 24.6 & $\mathbf{2 . 9 8 4 7}$ \\
\hline Aim \& Objectives & 75.0 & 25.0 & 3.0164 \\
\hline Basic Historical Skill & 74.8 & 25.2 & 2.8936 \\
\hline History Across-Curriculum & 59.6 & 40.4 & $\mathbf{2 . 5 1 3 7}$ \\
\hline Values \& Citizenship & 82.9 & 17.1 & $\mathbf{3 . 1 1 5 0}$ \\
\hline Function \& Benefits & 80.3 & 19.7 & 3.0829 \\
\hline Interest & 71.8 & 28.2 & 2.8918 \\
\hline
\end{tabular}

Table 5.10 shows the general perception of students, and there are just two aspects, 'Values \& Citizenship' and 'Function \& Benefits', perceiving more than $80.0 \%$ responses. Four aspects are lower than $80 \%$ and the lowest is the aspect of history 'interconnecting curriculum' with $59.6 \%$.

General Discussion: The overall perception is apprehensive and insufficient. Students seem to lack of knowledge and comprehension of philosophy and objectives of history and it implies that they are 'narrow-minded' and 'half-hearted' to the lesson. The proficiency of 'little-historian' based on research and less excellence of effective learning suggests that they do not get pleasure from exploring and learning history. Furthermore, students almost fail to correlate it effectively with other subjects, whereas all lessons have history and it should the primary concern and scientific philosophy for its development and improvement.

This phenomenon should completely be followed up and the arising problems should be overcome immediately and effectively. It should be concerned that there could be sayings that learning history is 'boring', 'that it means learning numb matters', 'that it destabilizes the country', etc. Ultimately, it could be suggested to get rid of history as a primary concern and even to remove it from IT-Globalization-based school curriculum. If it happens, it will result in collateral damages, particularly to the loyalty of patriotism and harmony of citizenship as well as the great effort of indigenous natives that attain the independence of the country, nation, and religion with their tears, blood and life.

It is obvious that there are varied weaknesses in learning and teaching history according to the exploratory research conducted. Therefore, each aspect should be more cooperative and strongly committed to design more comprehensive and relevant curriculum of history. Principles and approaches of learning and teaching process should be adjusted and modified to be more effective and interesting for students. Besides, many aspects apart from formal education at schools should provide integrated, fair, authentic, and sincere support in actualizing facts, reality, and lessons of history. It is fully considered that total commitment and integrity to stimulate innovations of historical education in high schools will result in the eternity of thorough and promising development of the country. 


\section{Conclusion}

The study shows that the teaching and learning of history, ICSS, Malaysia had acquired certain level of impressive achievement towards the realization of producing first class human capital who truly conscious with the commitment pure citizenship. Congratulations to all, especially the role-model leaders, education policy makers, teachers, parents, and all those involved in enhancing history in the prestigious stage of core subject in the ICSS, Malaysia. Innovative and effective learning and teaching process of history attempts to generate next generation independence and sovereignty, chain of the country towards the enlightenment to become a developed country. Moreover, it is expected to achieve enormous success and to create successful civilization in the world history. Every action has weaknesses and people should be cooperative to take on the responsibility and trust for the beloved country, nation and religion. May Allah go along with our lifespan and bless our struggle, and may former generation can get happiness and excellence in the world and in the hereafter.

"Dozens of stories is not more impressive than a scrap of experience"

\section{REFERENCES}

Aldrich, R. (ed.) (1991). History in the National Curriculum, Kogan Page in association with the Institute of Education. University of London.

Andaya, B.W. and Leonard, Y. A. (1982). A History of Malaysia. MacMillian Histories Series. London.

Anderson, C. and Moore, A. (1994). 'Making history happen outside the classroom' in Hilary Bourdillon, (ed.). Teaching History. The Open University, London, pp. 196-208.

Andreetti, K. (1993). Teaching History from Primary Evidence. David Fulton Publishers in Association with Roehampton Institute, London.

Archer, A.P. (1985), The Place of Field Work in the Teaching and Learning of History. MA Dissertation (unpublished). Institute of Education, London.

Best, J.W., and Kahn, J.V. (1990). Research in Education-Sixth Edition, Prentice

Hall, Eaglewood Cliffs, New Jersey

Black, J. and MacRaild, D. M. (1997). Studying History. MacMillan, London. Blow, F. and Dickinson, A. (eds.) (1986). New History and New Technology:

Present into Future. The Historical Association. London.

Bourdillon, H.(ed.) (1994) Teaching History, The Open University, London.

Brooks, A. and Perry (1993). The Effective Teaching of History. Longman, London.

Cabinet Committee Report. (1979). Report Review on the Implementation of the National Education Policy. Ministry of Education. Kuala Lumpur. 
Carpenter, S. (1990), History Teaching: The Era Approach, Cambridge.

Carson, S. (ed.) (1978), Environmental Education: Principles and Practice, Edward Arnold Ltd., London.

Cobuild English Language Dictionary. (1993). Collins Cobuild English Language

Dictionary. (1993). Harper Collins Publisher. Glasgow.

Cohen, L. and Manion, L. (1994). Research Methods in Education. Routledge, London.

Cooper, H. (1992), The Teaching of History: Implementing the National Curriculum, London. David Fulton Publishers.

Dickinson, A. (ed) (1992). Perspectives on Change in History Education, Institute of Education. London.

Emanel, J.M., William, J.B. (1997). Research in Education and the Behavioral Sciences, Concepts and Methods. Brown \& Benchmark Publishers, London.

Marwick, A. (1989). The Nature of History. MacMillan, London.

McCullagh, C. B. (1998). The Truth of History. Routledge. London.

Ministry of Education Malaysia. (1988b). History Syllabus ICSS. Curriculum Development Centre. Kuala Lumpur.

Ministry of Education. (2008). Education In Malaysia, Education Planning and Research Division (EPRD). Kuala Lumpur. Malaysia.

Ministry of Education Malaysia. (1992). History Syllabus ICSS, Curriculum Development Centre. Kuala Lumpur.

Sebba, J. (1994). History for All. David Fulton. London.

Slater, J.(1992). 'Student Teacher's Perceptions of History in the National Curriculum', in Peter Lucas and Ruth Watts (eds.), Meeting the Challenge, Preparing Tomorrow's History Teachers. University of Sheffield.

Smith, L. and Holden, C. (1994). 'Using Artefacts in History Teaching', in Teaching History. June, The Historical Association, London.

Tosh, J. (1997). The Persuit of History, Aims, Methods \& New Directions in the Study of Modern History. (Eleven Edition; First Edition 1984), Longman, London.

Walsh, P. (1992). The Aims of School History: The National Curriculum and Beyond, Institute of Education. London.

Watts, R. (Autumn, 1993). Why Site Visit?, Welsh Historian, pp. 15-18.

Watts, R. and Grosvenor, I. (eds.) (1995). Crossing the Key Stages of History: Effective History Teaching 5-16 and beyond, David Fulton, London.

White, J. (March, 1994). 'The School Look Around', in Teaching History, The Historical Association. London. 